\title{
Simulation of indoor solar illumination system for a library hall in Baghdad city
}

\author{
Hisham A. Maliek, Sawsan K. Fandi, Zahraa A. Hussan \\ Ministry of Science \& Technology \\ E-mail: hushamabid@yahoo.com
}

\begin{abstract}
A concept of indoor solar illumination is described and simulated. The solar illumination system is composed of a tracking primary reflector, a selective secondary reflector, a visible light guide and a scattering solid glass tube fixture. Each part of the solar illumination system is optically suited and compatible with other parts to realize high efficiency. The simulation is conducted for Baghdad city for a library hall. Two major days over a year are chosen to investigate the illumination system for acceptable visible light level for reading hall. The two days are: summer solstice day and winter solstice day at 8:00 AM and 12:00 PM for each. Research results showed that the design of the solar system is achieved on the base of minimum solar illuminance level at the starting day for office work at 8:00 AM on

21 December. Aluminum coated dish is the preferred comparing with silver coated dish which their solar illuminance for one meter dish diameter are so close for reading hall visible light level. Their values are 538Lux for Aluminum and 589Lux for Silver.
\end{abstract}

Key words

Simulation, Solar illuminance, Primary reflector, Cold mirror, Solstice day.

\section{Article info}

Received: Oct. 2012

Accepted: Feb. 2013

Published: Apr. 2013

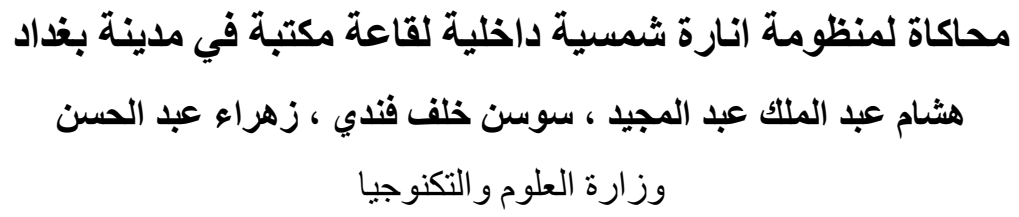

الخلاصة

فكرة الانارة الثمسية الداخلية قد تم وصفها و محاكاتها. تتألف منظومة الانارة الثمسية من عاكس اولي منتبع و عاكس ثنانوي

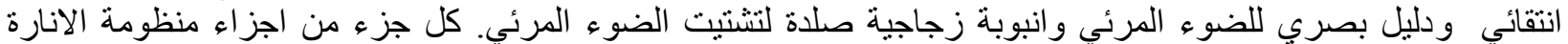

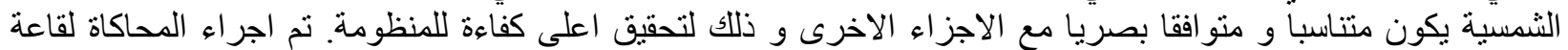

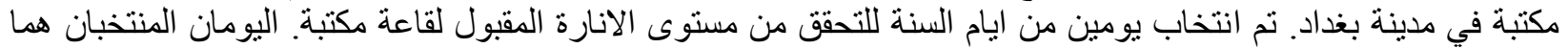

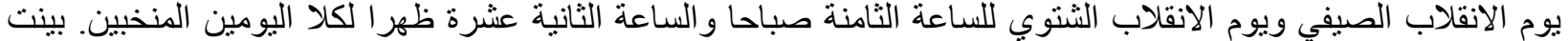

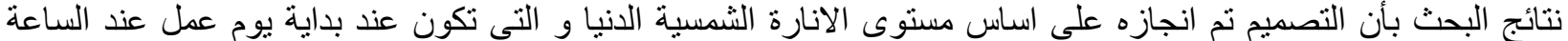

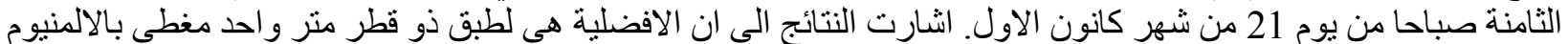

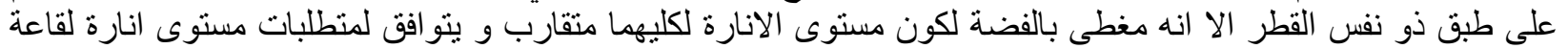

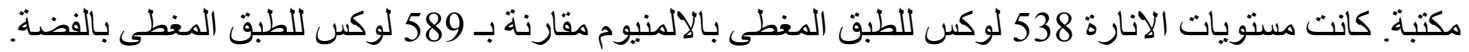

\section{Introduction}

Solar daylighting is a technology that flexibly brings sunlight inside buildings to decrease the electricity needed for lighting, to provide natural light, and to decrease the energy needed for cooling (as the technology displaces electrical lighting loads). The sunlight is collected on a rooftop using a tracking solar concentrator. The light 
is focused into fiber optics that carries the light down into the building below [1]. The fiber optics can be routed around obstacles to deliver light into spaces that would be inaccessible via other daylighting options. The sunlight can then be integrated with the existing lighting infrastructure via modified luminaries, or via stand alone sunlighting fixtures that augment the existing fixtures [2]. A daylight harvesting sensor completes the integration package by allowing the electrical lighting load to be reduced commensurate with the available sunlight. This integration, which adds the "hybrid" to the technology name, allows the electric lights to be dimmed when the sun is bright or run at full power during the night or when it is cloudy. This enables a constant level of lighting inside the building [3].

\section{Principle of Operation}

The solar lighting system uses a roof-mounted solar collector Fig. 1 to concentrate visible sunlight into a bundle of plastic optical fibers. The optical fibers penetrate the roof and distribute the sunlight to multiple luminaries within the building. The hybrid luminaries blend the natural light with artificial light (of variable intensity) to maintain a constant level of room lighting.

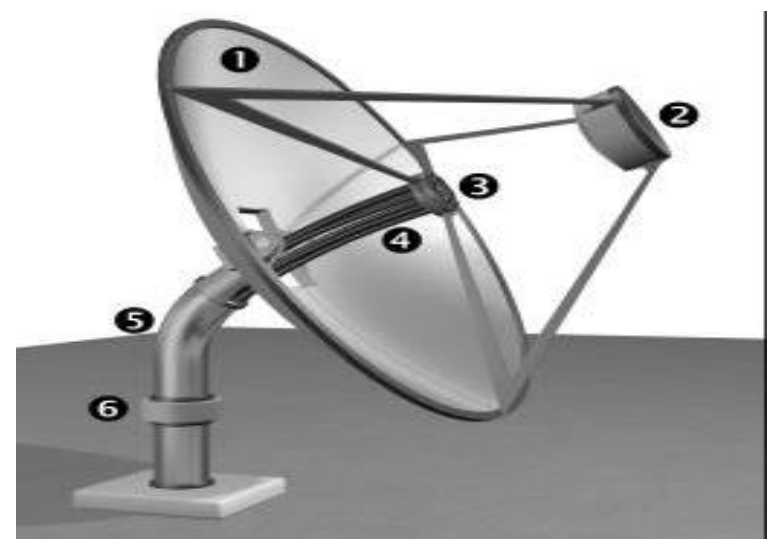

Fig.1: Solar lighting system, where 1 is primary reflector, 2 is secondary reflector, 3 is fiber mount, 4 is large core optical fiber, 5 is angled stand with altitude tracking mechanism, and 6 is azimuth tracking mechanism [4].

When sunlight is plentiful, the fiber optics in the luminaries provides all or most of the light needed in an area. During times of little or no sunlight, a sensor controls the intensity of the artificial lamps to maintain a desired illumination level. Unlike conventional electric lamps, the natural light produces little to no waste heat, having an efficacy of 200 lumens/Watt and is cool to the touch. This is because the system's solar collector removes the infrared (IR) light from the sunlight - the part of the spectrum that generates much of the heat in conventional bulbs. Because the optical fibers lose light as their length increases, it makes sense right now to use hybrid solar lighting in top-story or single-story spaces [5].

\section{Solar Lighting System Simulation}

Simulating solar lighting system needs knowing all technical details of all optical elements composing the system [6], which are:

1 - Primary reflector (dish) coated with highly reflective material of given reflectivity $(\rho)$. The geometrical dimensions should also be given, such as: diameter (d), depth (h), focal length (f), rim angle ( $\left.\psi_{\text {rim }}\right)$, parabolic radius $(p)$, and surface area $\left(A_{s}\right)$, see Fig. 2. 


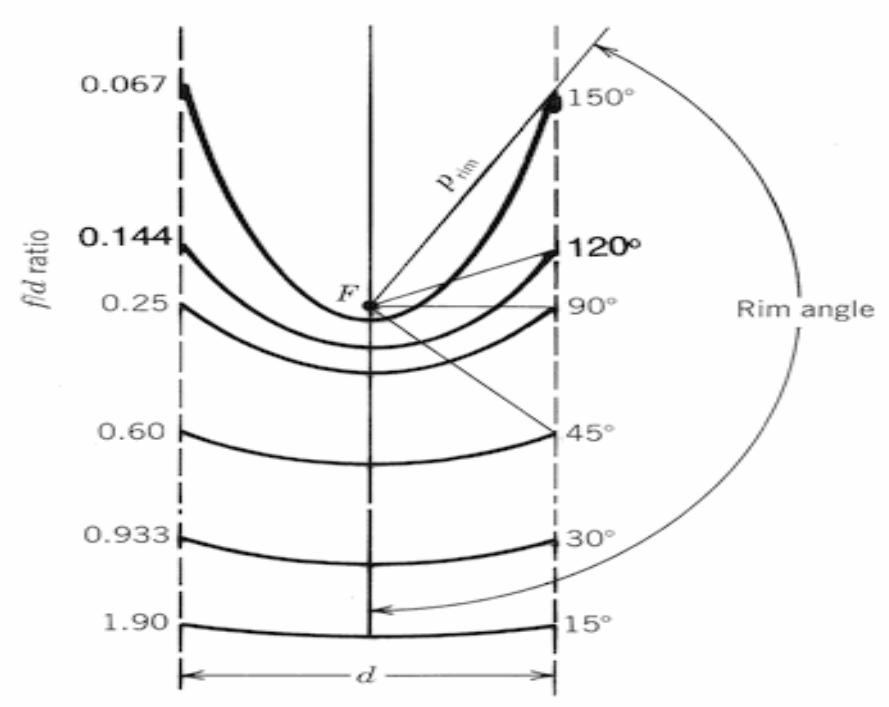

Fig.2: Shows geometrical dimensions of primary reflector (dish) [7].

2 - Secondary reflector (cold mirror) is a selective optical element; material of this element is Borosilicate coated glass .Cold mirror is used to separate IR from the solar spectrum. It transmits IR bands (hot band) and reflects visible band (cool light). Transmittance and reflectivity of this element should be given and visible portion percentage should be known.

3 - Plastic optical fiber (POF) is prepared to guide visible light to the interior. POF has large diameter to contain diameter of concentrated sun spot image to maintain high efficiency of this element and also has large numerical aperture, NA. POF has the type of polymethyl methacrylate, PMMA. Diameter, length, NA and average attenuation of the POF should be known. 4 - Grooved glass rod is prepared to scatter visible light transmitted from POF. This rod plays the role of a fluorescent tube but without electricity. Grooves on the surface of the glass rod guide the direction of scattered visible light, see Fig.3.

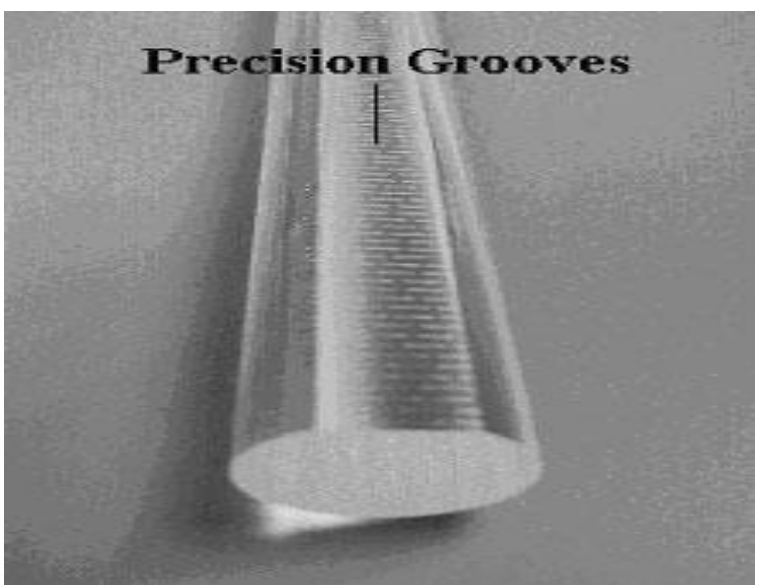

Fig.3: Grooved glass rod for scattering solar visible light [8].

\section{Simulation Related Equations}

Performance efficiency of solar illuminance system is determined by simulating the related equations which describe the geometrical dimensions of the system as follows [9]:

1 - Primary Reflector (dish)

Dish depth is calculated as:

$h=\frac{d^{2}}{16 f}$

Dish focal length is calculated as:

$$
f=\frac{d}{4 \tan \left(\frac{\psi_{\text {rim }}}{2}\right)}
$$

Dish surface area is calculated as:

$$
A_{s}=\frac{8 \pi f^{2}}{3}\left\{\left[\left(\frac{d}{4 f}\right)^{2}+1\right]^{\frac{3}{2}}-1\right\}
$$

Dish geometric concentration ratio is calculated as:

$C_{r}=\frac{A_{s}}{A_{r}}$

where $A_{r}$ is receiver area, in our research it will be area of sun spot image concentrated on the cold mirror which will be then reflected to the plastic optical fiber. 
2- Secondary mirror (cold mirror) is of given data (transmittance and reflectivity).

3 - Plastic optical fiber transmission $\left(\mathrm{T}_{\mathrm{pof}}\right)$ is constrained by its length $\left(\mathrm{L}_{\mathrm{f}}\right)$ and average attenuation coefficient $\left(\alpha_{\mathrm{f}}\right)$ as follows:

$T_{p o f}=10^{\frac{-\alpha_{f} L_{f}}{10}}$

4 - Scattering glass rod transmission ( $\mathrm{T}_{\text {glass }}$ ) is also constrained by its length $\left(\mathrm{L}_{\mathrm{g}}\right)$ and average attenuation coefficient $\left(\alpha_{\mathrm{g}}\right)$ as follows:

$T_{\text {glass }}=e^{-\alpha_{g} L_{g}}$

Methodology

Methodology of this paper is conducted simulation program for daylighting illumination system to design the required optical elements dimensions as optimum values are based on the following key parameters [10]:

1 - The city at which the designer has to conduct his simulation, namely the latitude, 2 - The time period over a day at which solar flux has minimum and maximum values,

3 - The major and minor days for solar flux levels over a year,

4 - The acceptable visible light level for reading hall in photometric scale.

Solar irradiance (I) that reaches the earth's surface is based on Hottel's Clear - Day Model [11]

and given as:

$\mathrm{I}=\mathrm{I}_{\mathrm{n}}+\mathrm{I}_{\mathrm{d}}+\mathrm{I}_{\mathrm{r}}$

where $I_{n}$ is direct normal beam solar irradiance,

$\mathrm{I}_{\mathrm{d}}$ is diffused solar irradiance.

$\mathrm{I}_{\mathrm{r}}$ is reflected solar irradiance.

$I_{n}=I_{o}\left[a_{o}+a_{1} e^{-k \frac{1}{\cos \left(\theta_{Z}\right)}}\right]$

where $I_{0}$ is extraterrestrial solar irradiance and given as:
$I_{o}=I_{S C}\left[1+0.034 \cos \left(\frac{360 n}{365.25}\right)\right]$

where $\mathrm{I}_{\mathrm{SC}}$ is solar constant, its value is $1367 \mathrm{~W} / \mathrm{m}^{2}$

$\mathrm{n}$ is Julian day.

$\theta_{\mathrm{z}}$ is the solar zenith angle. The parameters $a_{0}, a_{1}$ and $k$ are given below for clear atmosphere.

$\mathrm{a}_{\mathrm{o}}=0.4237-0.00821(6-\mathrm{A})^{2}$

$\mathrm{a}_{1}=0.5055+0.00595(6.5-\mathrm{A})^{2}$

$\mathrm{k}=0.2711+0.01858(2.5-\mathrm{A})^{2}$

where $\mathrm{A}$ is the local elevation in kilometers.

\section{Results and Discussion}

To design an optimum parabolic dish has highest geometrical concentration ratio, a relationship between concentration ratio of the parabolic dish and its rim angle should be considered carefully, see Fig. 5.

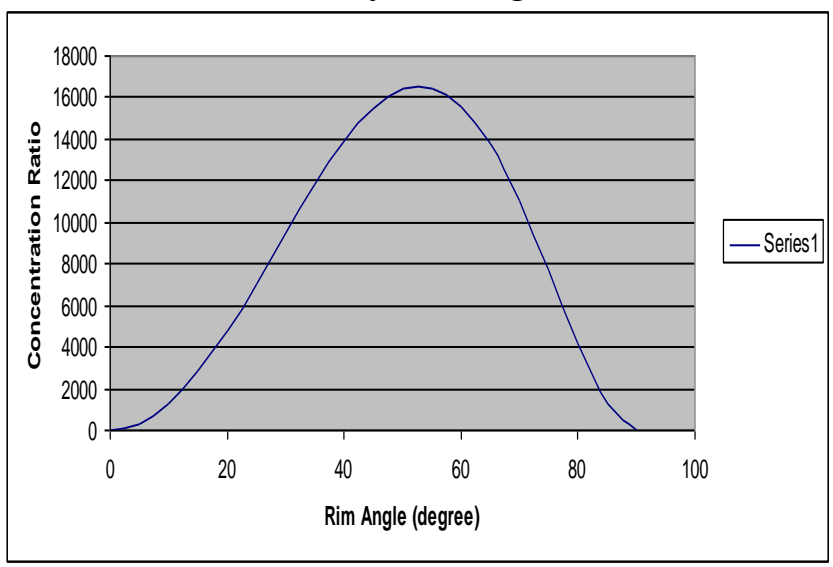

Fig.5: Shows the relationship concentration ratio of the parabolic dish and rim angle.

It is clear that $\psi_{\text {rim }}=55^{\circ}$ is the optimum for highest concentration ratio. Now the key for geometrical design is obtained by knowing the optimum rim angle.

For choosing proper surface area for the dish, knowing the solar irradiance over a year for Baghdad city (Latitude is $\varphi=33^{\circ}$ $20^{\prime} \mathrm{N}$ ) will make the choice easy. Maximum and minimum levels for solar irradiance are the base for electing the corresponding days over the year. June $21^{\text {th }}$ is the maximum 
level while Dec. $21^{\text {th }}$ is the minimum level, see Fig. 6.

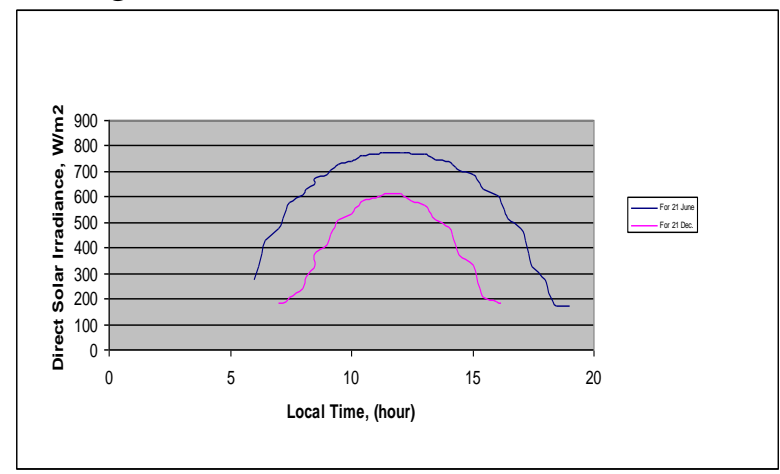

Fig.6: Shows the behavior of direct solar irradiance for chosen days.

The optical system for direct solar irradiance is designed according to two major days over a year, namely the solstice days on 21 June and 21 December, see Table 1.

Table1: Shows simulated direct solar irradiance reaches Baghdad city for chosen days.

\begin{tabular}{|c|c|c|}
\hline Day & Time & $\begin{array}{c}\text { Direct Solar } \\
\text { Irradiance, W/m2 }\end{array}$ \\
\hline \multirow{2}{*}{ 21 June } & $8: 00 \mathrm{AM}$ & 608.1776 \\
\cline { 2 - 3 } & $12: 00 \mathrm{PM}$ & 773.7154 \\
\hline \multirow{2}{*}{21 Dec. } & $8: \mathrm{AM}$ & 241.5614 \\
\cline { 2 - 3 } & $12: 00 \mathrm{PM}$ & 614.1756 \\
\hline
\end{tabular}

Optical Elements Efficiencies

Applying different parabolic dish diameters versus reflected direct solar irradiance for chosen days are shown in Fig.7.

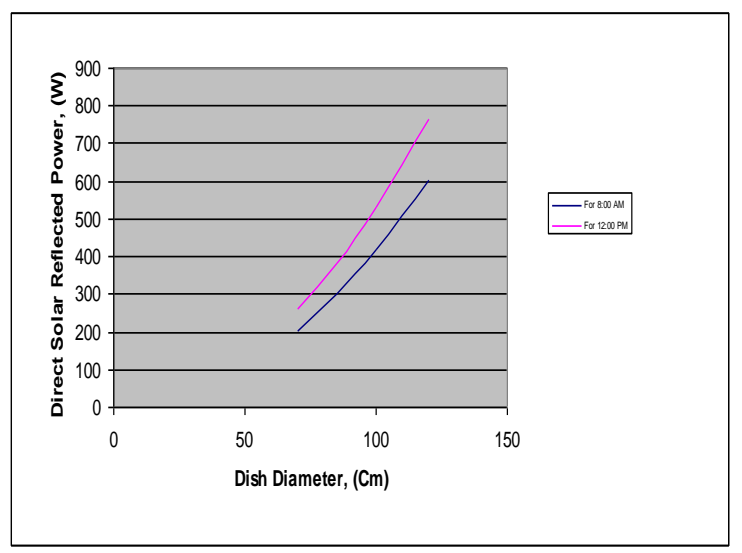

(a)

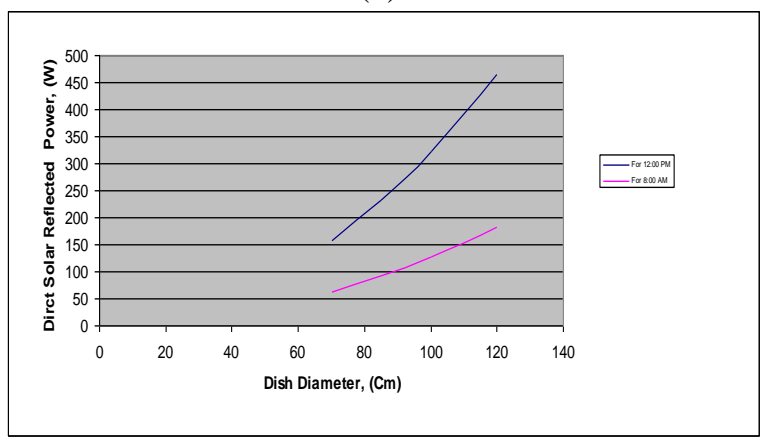

(b)

Fig.7: Shows different parabolic dish diameters versus reflected direct solar power for (a) 21 June (b) 21 December.

Reflected visible solar power from the cold mirror is shown in Fig.8.

Table2: Shows efficiencies of solar lighting optical elements.

\begin{tabular}{|c|c|}
\hline Optical Element & Optical Efficiency \\
\hline $\begin{array}{c}\text { Primary Reflector } \\
\text { (Parabolic Dish) }\end{array}$ & $82.08778 \%$ \\
\hline $\begin{array}{c}\text { Selective Secondary } \\
\text { Reflector (Cold } \\
\text { Mirror) }\end{array}$ & $40.5 \%$ \\
\hline $\begin{array}{c}\text { Plastic Optical Fiber } \\
\text { (POF) }\end{array}$ & $\begin{array}{c}54.056 \% @\left(\mathrm{~L}_{\mathrm{f}}\right. \\
=10 \mathrm{~m}, \alpha_{\mathrm{f}}=0.25 \\
\mathrm{~dB} / \mathrm{m})\end{array}$ \\
\hline Scattering Glass Rod & $\begin{array}{c}47.49 \% @ \mathrm{~L}_{\mathrm{g}}=1 \\
\left.\mathrm{~m}, \alpha_{\mathrm{g}}=10^{-5} \mathrm{~mm}^{-1}\right)\end{array}$ \\
\hline
\end{tabular}



(a) 




(b)

Fig.8: Shows reflected visible solar power from the cold mirror versus dish diameter for (a) 21 June (b) 21 December.

Transmitted visible solar power from the plastic optical fiber is shown in Fig. 9.



(a)

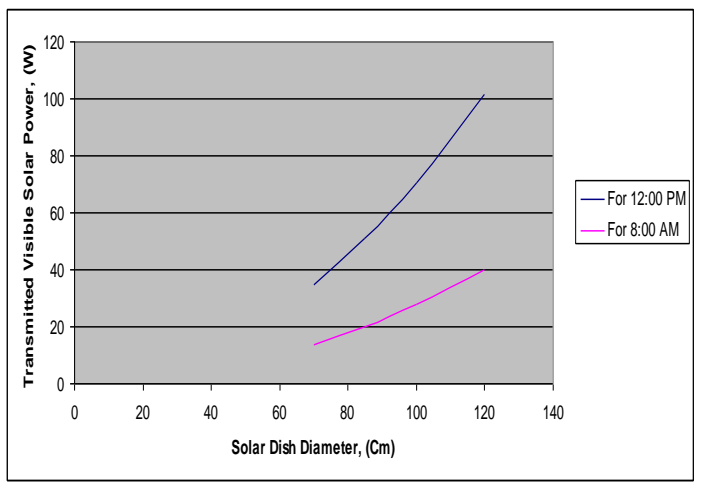

(b)

Fig.9: Shows transmitted visible solar power from the POF versus dish diameter for (a) 21 June (b) 21 December.

Scattered visible solar power from the glass rod is shown in Fig. 10.

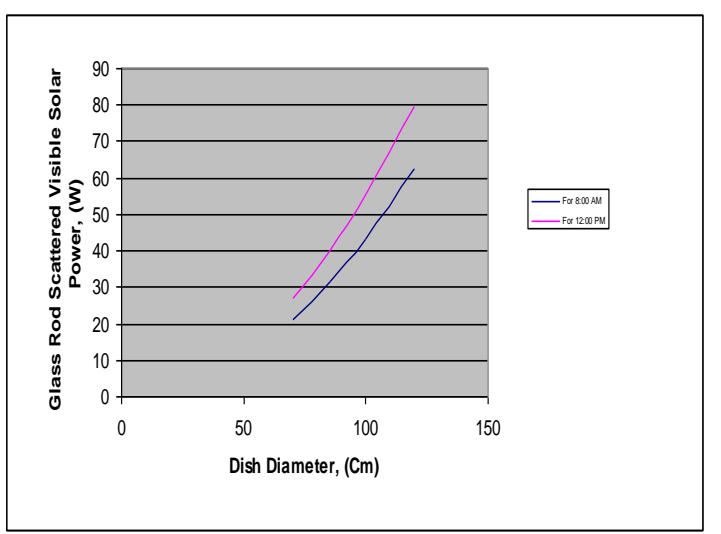

(a)

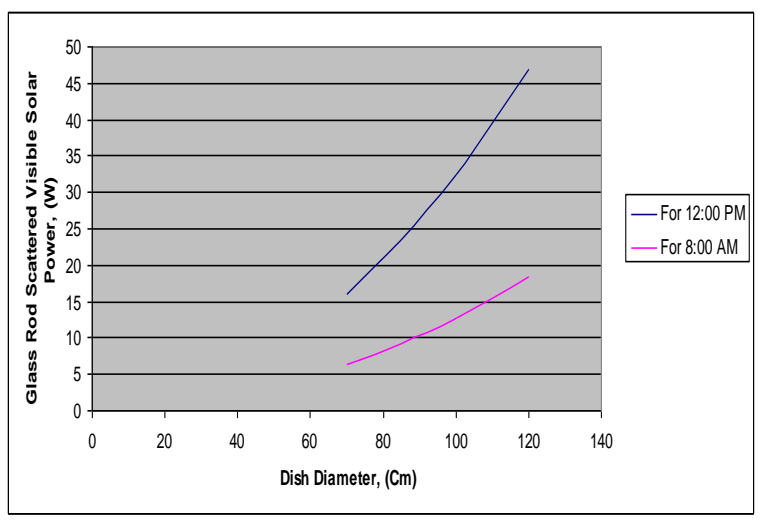

(b)

Fig.10: Shows scattered visible solar power from the glass rod versus dish diameter for (a) 21 June (b) 21 December.

Scattered visible solar luminous flux from the glass rod is shown in Fig. 11.

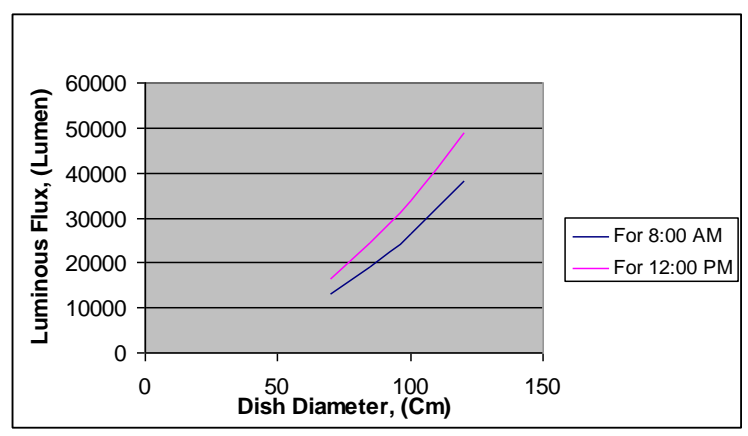

(a) 


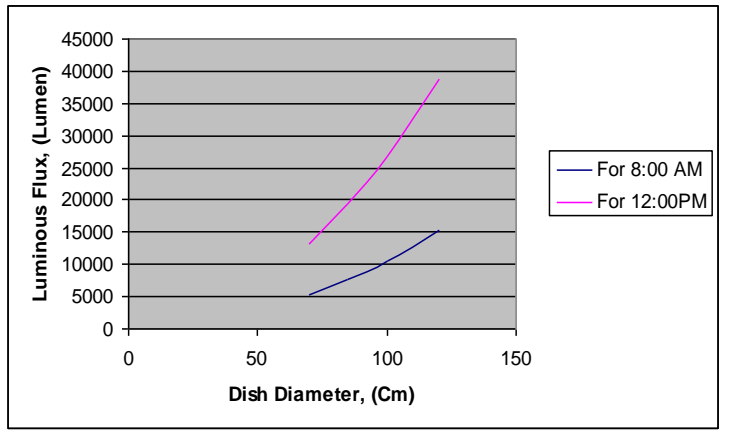

(b)

Fig.11: Shows scattered visible solar luminous flux from the glass rod versus dish diameter for (a) 21 June (b) 21 December.

Scattered visible solar illuminance from the glass rod is shown in Fig. 12.

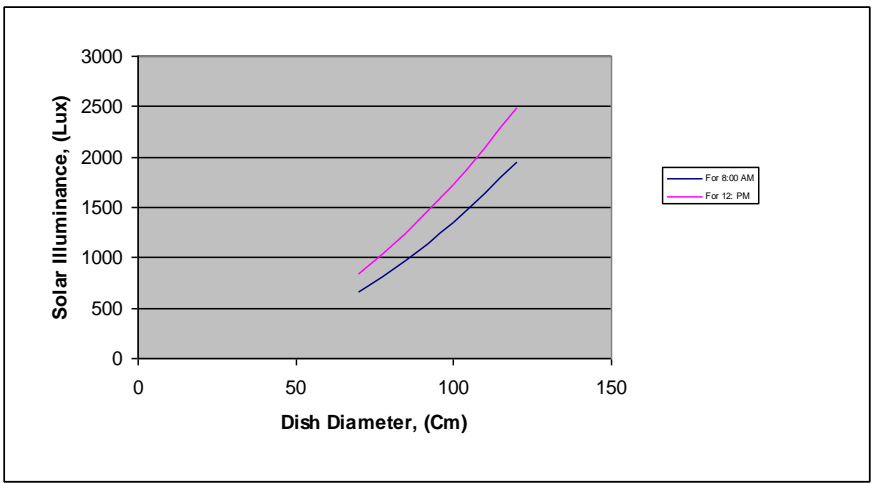

(a)

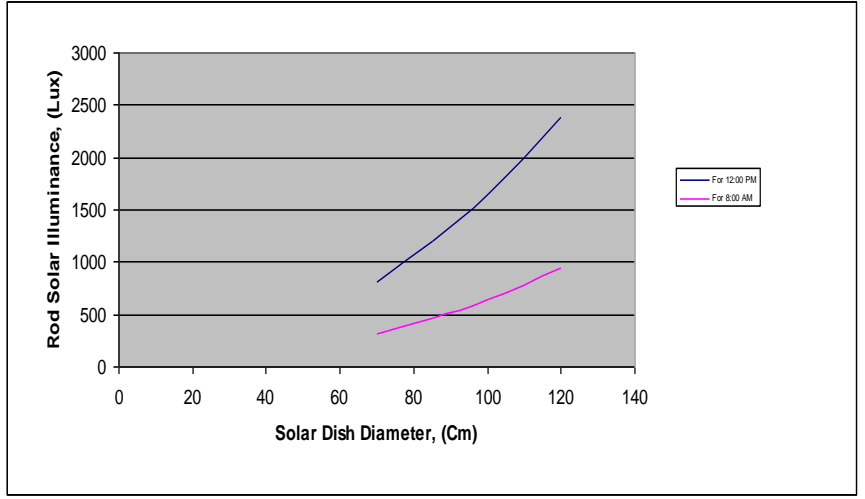

(b)

Fig.12: Scattered visible solar illuminance from the glass rod versus dish diameter for (a) 21 June (b) 21 December.

To find the proper illuminance for human eye, see Table (3) which shows the level of each case as follows:

Table 3: Illuminance for human eye level of different cases.

\begin{tabular}{|c|c|}
\hline Illuminance, (lux) & Example \\
\hline $10^{-4}$ & Total starlight, overcast sky [12]. \\
\hline 0.002 & Moonless clear night with airglow [13]. \\
\hline 0.01 & Quarter moon. \\
\hline 0.27 & Full moon on a clear night [12] [14]. \\
\hline 1.0 & Full moon overhead at tropical latitudes [15]. \\
\hline 3.4 & Dark limit of civil twilight under a clear sky [16]. \\
\hline 50 & Family living room [18]. \\
\hline
\end{tabular}




\begin{tabular}{|c|c|}
\hline 80 & Hallway / toilet [12] [18]. \\
\hline 100 & Very dark overcast day [12]. \\
\hline 400 & Sunrise or sunset on a clear day. \\
\hline 500 & Office lighting [12] [13] [14]. \\
\hline 1000 & Overcast day [12], typical TV studio lighting. \\
\hline $10000-25000$ & Full daylight (not direct sun) [19]. \\
\hline $32000-130000$ & Direct sunlight. \\
\hline
\end{tabular}

For reading hall, the corresponding item in above mentioned table; office lighting is the proper choice which matches 500 lux.

Table 4: Different dish diameters versus different geometric dish parameters and solar irradiance for chosen days.

\begin{tabular}{|c|c|c|c|c|c|c|}
\hline $\begin{array}{l}\text { Dish Width } \\
\quad(\mathrm{cm})\end{array}$ & Date & Time & $\begin{array}{c}\text { Direct Solar } \\
\text { Light } \\
\left(\mathrm{W} / \mathrm{m}^{2}\right)\end{array}$ & $\begin{array}{c}\text { Reflector } \\
\text { Material } \\
\text { Type }\end{array}$ & $\begin{array}{l}\text { Lumen } \\
(\mathrm{Lm})\end{array}$ & $\begin{array}{c}\mathrm{Lux} \\
\left(\mathrm{Lm} / \mathrm{m}^{2}\right)\end{array}$ \\
\hline \multirow[t]{8}{*}{70.0} & \multirow[t]{4}{*}{21 Jun. } & \multirow[t]{2}{*}{ 8:00 AM } & \multirow[t]{2}{*}{608.1776} & $\mathrm{Al}$ & 13022.42 & 663.7982 \\
\hline & & & & $\mathrm{Ag}$ & 14233.81 & 725.5469 \\
\hline & & \multirow[t]{2}{*}{ 12:00 PM } & \multirow[t]{2}{*}{773.7154} & $\mathrm{Al}$ & 16566.95 & 844.4752 \\
\hline & & & & $\mathrm{Ag}$ & 18108.06 & 923.0311 \\
\hline & \multirow[t]{4}{*}{21 Dec. } & \multirow[t]{2}{*}{$8: 00 \mathrm{AM}$} & \multirow[t]{2}{*}{241.5614} & $\mathrm{Al}$ & 1572.361 & 263.6533 \\
\hline & & & & $\mathrm{Ag}$ & 5653.511 & 288.1792 \\
\hline & & \multirow[t]{2}{*}{ 12:00 PM } & \multirow[t]{2}{*}{614.1756} & $\mathrm{Al}$ & 13150.85 & 670.3447 \\
\hline & & & & $\mathrm{Ag}$ & 14374.18 & 732.7024 \\
\hline \multirow[t]{8}{*}{85.0} & \multirow[t]{4}{*}{21 Jun. } & \multirow[t]{2}{*}{ 8:00 AM } & \multirow[t]{2}{*}{608.1776} & $\mathrm{Al}$ & 19220.43 & 979.7324 \\
\hline & & & & $\mathrm{Ag}$ & 21008.38 & 1070.87 \\
\hline & & \multirow[t]{2}{*}{ 12:00 PM } & \multirow[t]{2}{*}{773.7154} & $\mathrm{Al}$ & 24451.97 & 1246.402 \\
\hline & & & & $\mathrm{Ag}$ & 26726.57 & 1362.347 \\
\hline & \multirow[t]{4}{*}{21 Dec. } & \multirow[t]{2}{*}{ 8:00 AM } & \multirow[t]{2}{*}{241.5614} & $\mathrm{Al}$ & 7634.142 & 389.1389 \\
\hline & & & & $\mathrm{Ag}$ & 8344.295 & 425.3378 \\
\hline & & \multirow[t]{2}{*}{ 12:00 PM } & \multirow[t]{2}{*}{614.1756} & $\mathrm{Al}$ & 19409.99 & 989.3947 \\
\hline & & & & $\mathrm{Ag}$ & 21215.56 & 1081.432 \\
\hline \multirow[t]{8}{*}{100.0} & \multirow[t]{4}{*}{21 Jun. } & \multirow[t]{2}{*}{ 8:00 AM } & \multirow[t]{2}{*}{608.1776} & $\mathrm{Al}$ & 26618.05 & 1356.815 \\
\hline & & & & $\mathrm{Ag}$ & 29094.15 & 1483.03 \\
\hline & & \multirow[t]{2}{*}{ 12:00 PM } & \multirow[t]{2}{*}{773.7154} & $\mathrm{Al}$ & 33863.13 & 1726.122 \\
\hline & & & & $\mathrm{Ag}$ & 37013.18 & 1886.691 \\
\hline & \multirow[t]{4}{*}{21 Dec. } & 8:00 AM & 241.5614 & $\mathrm{Al}$ & 10572.4 & 538.912 \\
\hline & & & & $\mathrm{Ag}$ & 11555.87 & 589.0433 \\
\hline & & 12:00 PM & 614.1756 & $\mathrm{Al}$ & 26880.56 & 1370.196 \\
\hline & & & & $\mathrm{Ag}$ & 29381.08 & 1497.656 \\
\hline 120.0 & 21 Jun. & 8:00 AM & 608.1776 & $\mathrm{Al}$ & 38347.62 & 1954.712 \\
\hline & & & & $\mathrm{Ag}$ & 41914.84 & 2136.546 \\
\hline & & 12:00 PM & 773.7154 & $\mathrm{Al}$ & 48785.32 & 2486.759 \\
\hline & & & & $\mathrm{Ag}$ & 53323.5 & 2718.085 \\
\hline & 21 Dec. & $8: 00$ AM & 241.5614 & $\mathrm{Al}$ & 15231.25 & 776.39 \\
\hline & & & & $\mathrm{Ag}$ & 16648.11 & 848.6123 \\
\hline & & 12:00 PM & 614.1756 & $\mathrm{Al}$ & 38725.81 & 1973.99 \\
\hline & & & & $\mathrm{Ag}$ & 42328.21 & 2157.617 \\
\hline
\end{tabular}

(Al) stands for aluminum coating and (Ag) stands for silver coating. 
Aluminum coated dish diameter of 1.0 meter is the threshold for solar illumination system for reading hall on 21 December at 8:00 AM.
The following technical data are given in Table 5 for system engineering.

Technical data

Table5: Technical data for solar illumination system design.

\begin{tabular}{|l|l|l|l|}
\hline Optical Element & Parameter & Unit & Amount \\
\hline \multirow{5}{*}{ Parabolic Dish } & Diameter, $\mathrm{d}$ & $(\mathrm{m})$ & 1.0 \\
\cline { 2 - 4 } & Rim Angle, $\psi_{\text {rim }}$ & $($ Degree $)$ & $55^{\circ}$ \\
\cline { 2 - 4 } & Focal Length, $\mathrm{F}$ & $(\mathrm{cm})$ & 48.0 \\
\cline { 2 - 4 } & Depth, $\mathrm{h}$ & $(\mathrm{cm})$ & 13.02 \\
\cline { 2 - 4 } & Surface Area, $\mathrm{A}_{\mathrm{s}}$ & $\left(\mathrm{m}^{2}\right)$ & 0.8355451 \\
\cline { 2 - 4 } & Surface Reflectivity, $\rho_{\mathrm{d}}$ & $(\%)$ & 86.0 \\
\cline { 2 - 4 } & Concentration Ratio, $\mathrm{C}_{\mathrm{r}}$ & - & 16443 \\
\cline { 2 - 4 } & Concentrated Spot Diameter, $\mathrm{S}_{\mathrm{d}}$ & $(\mathrm{mm})$ & 8.041 \\
\hline \multirow{5}{*}{ Pold Mirror } & Spectral Range & $(\mathrm{nm})$ & $380-740$ \\
\cline { 2 - 4 } & Reflectivity, $\rho_{\mathrm{m}}$ & $(\%)$ & 90.0 \\
\cline { 2 - 4 } & Diameter, $\varphi$ & $(\mathrm{mm})$ & 30.0 \\
\hline & Length, $\mathrm{L}_{\mathrm{f}}$ & $(\mathrm{m})$ & 10.0 \\
\cline { 2 - 4 } & Diameter, $\mathrm{d}_{\mathrm{f}}$ & $(\mathrm{mm})$ & 10.776 \\
\cline { 2 - 4 } & Core Refractive Index, $\mathrm{n}_{\mathrm{f}}$ & - & 1.49 \\
\cline { 2 - 4 } & Attenuation Coefficient, $\alpha_{\mathrm{f}}$ & $(\mathrm{dB} / \mathrm{m})$ & 0.25 \\
\cline { 2 - 4 } & Numerical Aperture, $\mathrm{NA}$ & - & 0.5 \\
\hline \multirow{5}{*}{ Glass Rod } & Length, $\mathrm{L}_{\mathrm{g}}$ & $(\mathrm{m})$ & 1.0 \\
\cline { 2 - 4 } & Diameter, $\mathrm{d}_{\mathrm{g}}$ & $(\mathrm{cm})$ & 2.5 \\
\cline { 2 - 4 } & Attenuation Coefficient, $\alpha_{\mathrm{g}}$ & $\left.(\mathrm{mm})^{-1}\right)$ & $10^{-5}$ \\
\cline { 2 - 4 } & Illuminance Flux & $(\mathrm{Lux})$ & 538.912 \\
\hline
\end{tabular}

Applying Silver coated surface to the parabolic dish will increase the following parameters:

1 - Dish optical reflectivity will be increase to 94 rather than 86 for Aluminum.

2 - Dish optical efficiency will be increase to $89.7238 \%$ rather than $82.08778 \%$ for Aluminum.

3 - Solar illuminance will be 589.0433 Lux rather than 538.912 Lux.

\section{Conclusions}

Solar illuminance system is the new approach of cheap lighting for homes, buildings, offices and factories. This technique is an environment friendly. Implementation of this technique could be achieved by national efforts and their required items for composing are available in the local market. The design of the solar system is achieved on the base of minimum solar illuminance level over a year for Baghdad city at the starting day for office work at 8:00 AM. Aluminum coated dish (communication satellite dish, available in 
the local market) is the preferred comparing with silver coated dish which their solar illuminance for one meter dish diameter are so close for reading hall. Their values are 538.9 Lux for Aluminum and 589.04 Lux for Silver.

\section{References}

[1] J. Muhs, American Solar Energy Society, SOLAR2000.

[2] Dye, D., Wood, B.D., Fraas, L., and Muhs, J., Proceedings of the ASME International Solar Energy Society Conference, Hawaii, 2003.

[3] J. L. Lindsay, Applied Illumination Engineering, 2nd Edition, the Fairmont Press, Lilburn, Georgia, 1997, p. 395.

[4] D.D.Earl, , and L. C.Maxey, , SPIE 45th Annual Meeting. San Diego, Ltd. Political Science and Technology, SPIE, Bellingham, WA, 2003.

[5] J. D. Muhs, CADDET Energy Efficiency Newsletter December 2000, p. 6.

[6] D. D. Earl, J. D. Muhs, American Solar Energy Society,( 2001) April 21-25.

[7] Geyer, Micheal, Stine B., William, J. T. Lyle Center 2001.

[8] Maxey, L.C., D.D. Earl, and J.D. Muhs, SPIE Proceedings, San Diego, CA, International Society for Optical Energy. SPIE, Bellingham, WA. 2003.

[9] A. Rosemann , H. Kaase,. Solar Energy, 78 (2005) 772-780.
[10] J.D. Muhs, NCPV and Solar Program Review Meeting, NREL/CD-520-33586, 2003.

[11] H. C. Hottel, Solar Energy, 18, 2, (1976) 129.

[12] Radiometry and photometry in astronomy FAQ, section 7, Paul Schlyter. (1980).

[13] Roger Fouquet, Edward Elgar publishing, 2008 ISBN 1-84542-660-6, page 411.

[14] Bunning, Erwin; and Moser, Ilse (April. Proceedings of the National Academy of Sciences of the United States of America 62,4 (1969) 1018-1022. Retrieved 2006-1110.

[15] F. A. Barnes, Electro-Optics Handbook: Technical Series EOH-11, RCA Corporation, Harrison, NJ , 1974, p.70.

[16] Pears, Alan "Chapter 7: Appliance technologies and scope for emission reduction" Strategic Study of Household Energy and Greenhouse Issues. Australian Greenhouse Office. p. 61, (June, 1998).

[17] Australian Greenhouse Office (May, 2005). Working Energy Resource and Training Kit: Lighting. Archived from the original on April 15, 2007.

[18] W. Kim and Y. Koga, Building Environ 38 (2004) 1435-1442.

[19] Hanselaer P, Lootens C, Ryckaert W, Deconinck G, Rombauts P. Lighting Research \& Technology, June 2007. 